\title{
Survival, Effect Measures, and Impact Numbers After Dementia Diagnosis: A Matched Cohort Study [Corrigendum]
}

\author{
Garre-Olmo J, Ponjoan A, Inoriza JM, et al. Clin \\ Epidemiol. 2019;11:525-542.
}

Page 534, Acknowledgments, first sentence, the text "This study was supported by research grant PI05/01980 from the Spain's Ministry of Science and Innovation through the Carlos III Health Institute" should read "This study has been funded by Instituto de Salud Carlos III through the project "PI15/01980" (Co-funded by European Regional Development Fund/European Social Fund "A way to make Europe"/“Investing in your future")".

The authors apologize for this error.

\section{Publish your work in this journal}

Clinical Epidemiology is an international, peer-reviewed, open access, online journal focusing on disease and drug epidemiology, identification of risk factors and screening procedures to develop optimal preventative initiatives and programs. Specific topics include: diagnosis, prognosis, treatment, screening, prevention, risk factor modification, systematic reviews, risk \& safety of medical interventions, epidemiology \& biostatistical methods, and evaluation of guidelines, translational medicine, health policies \& economic evaluations. The manuscript management system is completely online and includes a very quick and fair peer-review system, which is all easy to use. 